Jurnal Biota Vol. 6 No. 2, 2020

78 | ISSN: 2460-7746 (online); ISSN: 2528-262X (print)

\title{
In Vitro Antimicrobial Activity of Zodia (Evodia suaveolens) Leaf Extract on Pathogenic Agents Dragon Fruit Plant
}

\author{
Trio Ageng Prayitno ${ }^{*}$, Nuril Hidayati ${ }^{2}$ \\ ${ }^{1,2}$ Department of Biology Education, Faculty of Exact and Sport Science Education, IKIP Budi \\ Utomo \\ *email: trioageng@gmail.com
}

\begin{tabular}{l} 
Article Info \\
\hline Key word: \\
Antimicrobial \\
Evodia suaveolens \\
Pathogenic Agents \\
Article history: \\
Received: $14 / 07 / 2020$ \\
Revised: $20 / 08 / 2020$ \\
Accepted: $20 / 08 / 2020$
\end{tabular}

\begin{abstract}
The use of antimicrobials from plant extracts has not been used optimally to control pathogenic agents in dragon fruit plants. The purpose of this research was to determine the antimicrobial activity of zodia (Evodia suaveolens) leaf extracts on pathogenic agents of dragon fruit plants in vitro. The research method is laboratory research with Completely Randomized Design (CRD). The antimicrobial concentrations of zodia $(E$. suaveolens) leaf extract used six types including 50\%, 60\%, $70 \%, 80 \%$, 90\%, and $100 \%$ with four replications. The research sample was the leaf of zodia (E. suaveolens), Pseudomonas aeruginosa and Fusarium oxysporum strain Malang. Test the antimicrobial activity of zodia (E. suaveolens) leaf extracts on the growth of $P$. aeruginosa and $F$. oxysporum using the disc-diffusion method and wells method. The research instrument was used the observation sheet of the diameter of inhibition zone indicated by the clear zone. Diameter of inhibition zone data were analyzed using the One Way ANOVA test. The results showed that the antimicrobial activity of zodia (E. suaveolens) leaf extract significantly inhibited the growth of $P$. aeruginosa and $F$. oxysporum $(P<0.05)$. These results recommend zodia (E. suaveolens) leaf extract as an antimicrobial agent for dragon fruit plant pathogens.
\end{abstract}

Copyright $(2020$ Universitas Islam Negeri Raden Fatah Palembang. All Right Reserved

\section{Introduction}

Dragon fruit is a plant group of the Cactaceae family with the genus Hylocereus and also known as pitaya fruit is round, juicy, and nutritious (Jamilah, Shu, Kharidaah, Dzulkifly, \& Noranizan, 2011; Idris et al., 2013). Swastika, Yuliani and Saputra (2012) explained that dragon fruit plants in Indonesia consist of several species, such as Hylocereus undus, Hylocereus polyrhizus, Hylocereus megalanthus and Hylocereus costaricensis. An important benefit of dragon fruit for health is to facilitate the digestion process because it has lots of fiber, reduces body fat levels, prevents cancer because it contains antioxidants, and stimulates tissue formation because it is rich in vitamins and minerals (Swastika et al., 2012; (Noor, Yufita, \& Zulfalina, 2016).

In addition to the benefits above, dragon fruit has excellent sales prospects because prices in the market are high, stable and demand is high (Setiawan \& Soelistyo, 2017; Sudarjat, Suminar, Qanit, \& Mubarok, 2019; Paundrianagari, Setyowati, \& Qonita, 
2019). However, the superiority of the dragon fruit was not followed by good dragon fruit cultivation techniques by farmers. Therefore, many dragon fruit plants are attacked by diseases (Jumjunidang, D., \& Yanda, 2016).

Dragon fruit diseases found in Indonesia include stem and fruit cancers, anthracnose, and soft rot. Stem and fruit cancers are caused by Neocystalidium sp., Alternaria sp., and Pestaliopsis sp. Anthracnose is caused by Colletotrichum gloesporoides. Stem and fruit soft rot caused by Fusarium sp., Schlerotium sp., Alternaria sp., and Pseudomonas sp. (Riska et al, 2016; Wibowo, Widiastuti, \& Agustina, 2011; Swastika et al., 2012).

Recommendations for controlling microbial agents of dragon fruit disease currently using synthetic fungicidal compounds such as bordeux, propineb, copper hydroxide, benomil, mankozeb, and carbendazim (Riska et al., 2016; Jumjunidang et al., 2016; Widiastuti, Agustina, Wibowo, \& Sumardiyono, 2011). However, pesticides have negative effects on other organisms that have an important role in the ecosystem and the environment (Syromyatnikov, Isuwa, Savinkova, Derevshchikova, \& Popov, 2020; Maksymiv, 2015). So that these problems do not occur, it is recommended to use biocontrol agents and plant extracts to control plant pathogenic microbes (Abdel-Gaied, Mikhail, AbdelAlim, Seif El-Nasr, \& El-Khair, 2020).

One of the plants that can be recommended as an antimicrobial is zodia (E. suaveolens) because the results of isolation and identification of active compounds find essential oils that can be used as antimicrobials (Maryuni, 2008). Essential oils and other active compounds such as alkaloids, tannins, flavonoids, triterpenoids, saponins, glycosides, berberine, furoquinoline and evodiamine can inhibit growth and kill microbes (Fajri and Agustien, 2015); Rahmawati, Samsumaharto, \& Iryanto, 2015; Handayani and Nurcahyanti, 2015). Furthermore, zodia plants (E. suaveolens) are shrubs that have a height of $50-200 \mathrm{~cm}$ that are easily cultivated through seeds or stem cuttings (Rahayu,
Mairawita, \& Putra, 2008) and this plant is a yard ornamental plant (Prayitno \& Elan, 2018) making it easier to provide ingredients for antimicrobials. Research on antimicrobial compounds and the antimicrobial efficacy of zodia plants (Evodia suaveolens) has been conducted at several universities such as Maryuni (2008) from the Institut Pertanian Bogor, Handayani and Nurcahyanti (2015) from Universitas Negeri Semarang, Fajri and Agustien (2015) Universitas Andalas and Rahmawati, Samsumaharto, \& Iryanto (2015) from Universitas Setia Budi Semarang.

Maryuni (2008) used steam distillation methods and Gas Chromatography-Mass Spectrometry (GCMS) to isolate antimicrobial compounds and with the disc diffusion method for antimicrobial testing of Staphylococcus aureus, Staphylococcus epidermidis, Escherichia coli and Salmonella enteritidis. Handayani and Nurcahyanti (2015) used the maceration method and water distillation to obtain antimicrobial compounds. Fajri and Agustien (2015) used the disc diffusion method for antimicrobial tests on Escherichia coli and Staphylococcus aureus. Rahmawati, Samsumaharto, \& Iryanto (2015) used the maceration method to obtain antimicrobial compounds and delusional methods in test tubes.

Research on inhibiting the growth of microbes that cause soft rot in dragon fruit plants with plant extracts has not been done. Research Wibowo et al. (2011) and Riska et al. (2016) focused on collecting important diseases that attack dragon fruit plants in three centers of dragon fruit plants on the island of Java and in Indonesia. The use of zodia (E. suaveolens) leaf extract as an antimicrobial has not been studied. Although there is one result of research related to the antibacterial extract of zodia leaves against $P$. aeruginosa (Rahmawati, Samsumaharto, \& Iryanto W, 2015). However, the study wanted to prove the comparison of zodia leaf extract with n-hexane, chloroform, and water fractions using the tube dilution method and recommended that the highest concentration of zodia leaf extract and be effective in inhibiting bacterial growth by $50 \%$. However, this research is different from this 
research. This research uses the discdiffusion method and wells method with concentration that starts from $50 \%$ to $100 \%$. Isolation and identification of zodia leaf antibacterial compounds was carried out (Maryuni, 2008; Handayani and Nurcahyanti, 2015; Rahmawati, Samsumaharto, \& Iryanto, 2015). However, the active compounds contained in zodia leaf extracts have not been used to inhibit the growth of fungal pathogens such as $F$. oxysporum. Thus, the purpose of this study was to determine the antimicrobial activity of zodia (E. suaveolens) leaf extract on pathogenic agents of dragon fruit plants in vitro.

\section{Materials and Methods}

The research sample used fresh zodia (E. suaveolens) leaf and used all types of leaves both young and old, $P$. aeruginosa and $F$. oxysporum. The solvent used to extract zodia (E. suaveolens) leaves is $95 \%$ alcohol. Growth media for $P$. aeruginosa are Nutrient Agar (NA) and $F$. oxysporum is Potato Dextrose Agar (PDA). The tools used in research such as Petri dishes for the culture of bacteria and fungi. Oven for sterilizing utensils made of glass such as Petri dishes. Autoclave for sterilization of bacteria and fungi medium. Evaporator to obtain extracts of zodia leaf antimicrobial compounds. Calipers to measure the inhibition zone for bacterial and fungal growth. An ose needle to plant bacteria and fungi onto the plate medium. Laminar Air Flow (LAF) for sterile bacterial and fungal planting sites. Electric vortex to homogenize zodia leaf extract. Drill the cork to make a hole in the culture medium. Watman paper for disc paper material.

This research use a laboratory experimental method. The research design used Completely Randomized Design (CRD) with six concentrations of zodia $(E$. suaveolens) leaf extracts including $50 \%$, $60 \%, 70 \%, 80 \%, 80 \%, 90 \%$, and $100 \%$ and each consisted of four times repeated. The design of this study can be seen in Table 1 . The independent variable of the study was zodia (E. suaveolens) leaf extract and the dependent variable was the zone of growth inhibition of $P$. aeruginosa and $F$. oxysporum.

Table 1. Research Design Design of
antimicrobial activity of zodia $(E$.
suaveolens) leaf extract

\begin{tabular}{ccccc}
\hline \multirow{2}{*}{ Treatment } & \multicolumn{4}{c}{ Replicant } \\
\cline { 2 - 5 } & $\mathbf{1}$ & $\mathbf{2}$ & $\mathbf{3}$ & $\mathbf{4}$ \\
\hline P1 & P 1.1 & P1. 2 & P1. 3 & P1. 4 \\
P2 & P 2.1 & P2. 2 & P2. 3 & P2. 4 \\
P3 & P 3.1 & P3. 2 & P3. 3 & P3. 4 \\
P4 & P 4.1 & P4. 2 & P4. 3 & P4. 4 \\
P5 & P 5.1 & P5. 2 & P5. 3 & P5. 4 \\
P6 & P 6.1 & P6. 2 & P6. 3 & P6. 4 \\
K (+) & K (+).1 & K (+).2 & K (+).3 & K (+).4 \\
K (-) & K (-).1 & K (-).2 & K (-).3 & K (-).4 \\
\hline K (+) Fuarium
\end{tabular}

$\mathrm{K}(+)$ Fusarium oxysporum = synthetic antifungal; $\mathrm{K}$ (+) Pseudomonas aeruginosa $=$ chlorampenicol; K (-) F. oxysporum and P. aeruginosa $=$ aquadest

The research procedure is as follows. (1) sterilization of tools and materials. (2) Preparation of $P$. aeruginosa and $F$. oxysporum medium. (3) Regeneration of $P$. aeruginosa and $F$. oxysporum. (4) Making zodia (E. suaveolens) leaf extract through the maceration method with $95 \%$ alcohol solvent. (5) Making serial concentrations of zodia (E. suaveolens) leaf extracts. (6) Test the antimicrobial activity of zodia (E. suaveolens) leaf extracts against $P$. aeruginosa growth by disc-diffusion method and F. oxysporum by wells method.

The research instrument used was the observation sheet of $P$. aeruginosa and $F$. oxysporum growth diameter of inhibition zone. Inhibitory zones are indicated by clear zones and measured using calipers. The calipers are placed in the clear zone horizontally and vertically. Furthermore, the results of the measurement of the clear zone are averaged so that the expected inhibition zone is obtained. Diameter of inhibition zone data were analyzed using the One Way ANOVA test through SPSS software.

\section{Results and Discussion}

The average diameter of $P$. aeruginosa growth inhibition zones is presented in Table 1 . The average diameter of $F$. oxysporum growth inhibition zones can be seen in Table 2 . Research data on the antimicrobial activity of zodia (E. suaveolens) leaf extract is stated to be normally distributed (sig > 0,05) and 
homogeneous (sig > 0.05). The results of the One Way ANOVA test for diameter of inhibition zone of antimicrobial activity of zodia (E. suaveolens) leaf extracts against $P$. aeruginosa growth are presented in Table 3
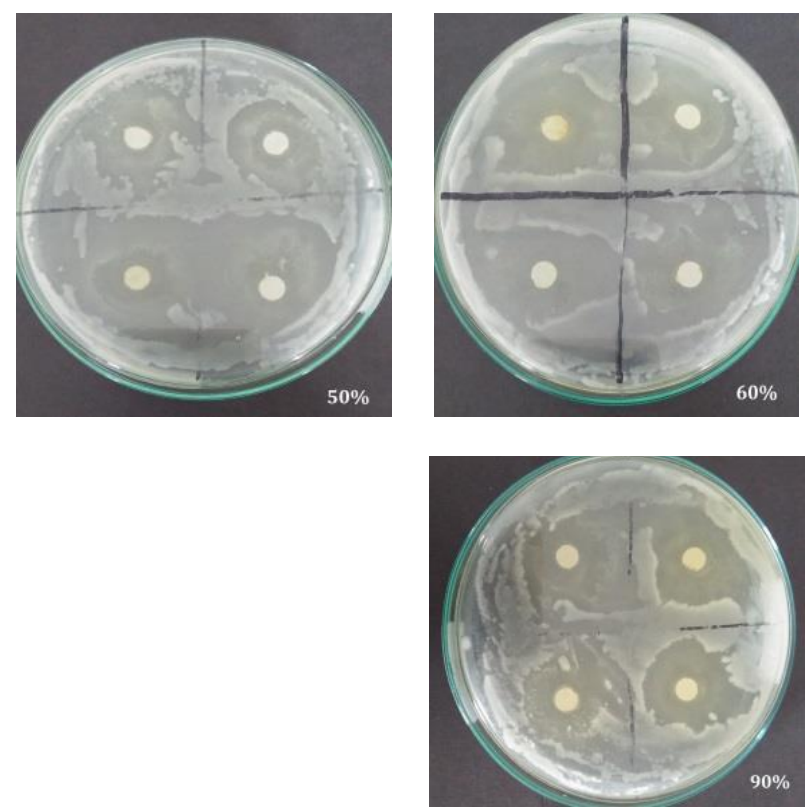

and $F$. oxysporum can be seen in Table 4 . The diameter of inhibition zone $P$. aeruginosa growth in several concentrations presented in Figure 1.
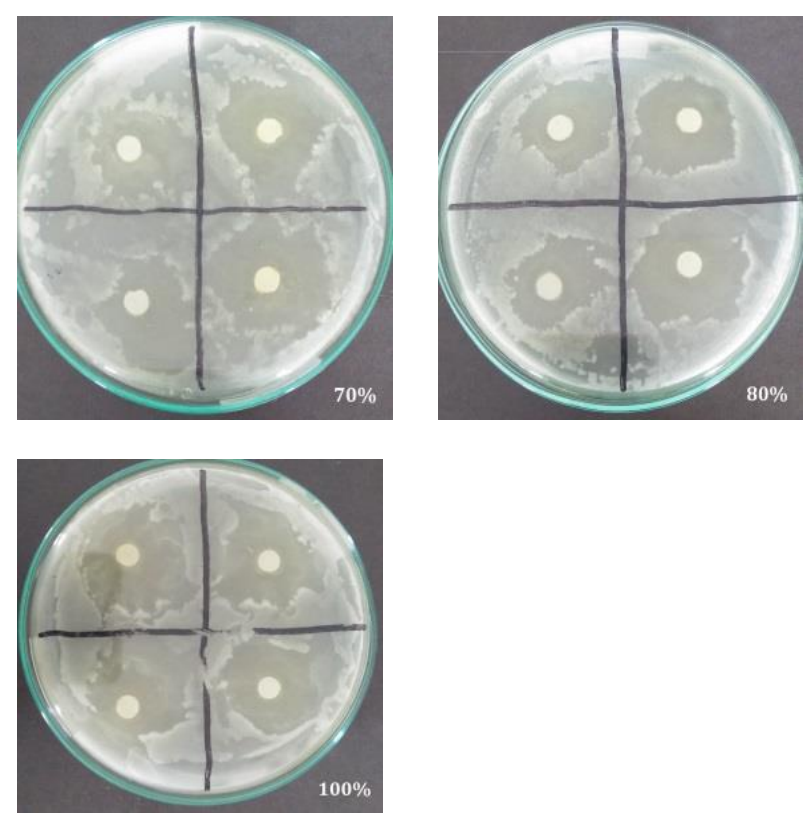

Figure 1. The Diameter of Inhibition Zone $P$. aeruginosa Growth in Several Concentrations of Zodia (E. suaveolens) Leaf Extract

Table 1. The Diameter of Inhibition Zone P. aeruginosa Growth

\begin{tabular}{ccccccc}
\hline \multirow{2}{*}{ Replicant } & \multicolumn{6}{c}{ Diameter of Inhibition Zone $(\mathbf{C m})$} \\
\cline { 2 - 7 } & $\mathbf{5 0 \%}$ & $\mathbf{6 0 \%}$ & $\mathbf{7 0 \%}$ & $\mathbf{8 0 \%}$ & $\mathbf{9 0 \%}$ & $\mathbf{1 0 0 \%}$ \\
\hline 1 & 1,76 & 1,78 & 2,02 & 2,39 & 2,44 & 2,79 \\
2 & 1,47 & 1,62 & 2,25 & 2,32 & 2,24 & 2,87 \\
3 & 1,23 & 1,78 & 2,15 & 2,00 & 2,59 & 2,43 \\
4 & 1,56 & 1,57 & 2,47 & 2,41 & 2,43 & 2,40 \\
Average & 1,51 & 1,69 & 2,22 & 2,28 & 2,43 & 2,62 \\
Std. Deviation & 0,22 & 0,11 & 0,19 & 0,19 & 0,14 & 0,24 \\
\hline
\end{tabular}

Table 2. The Diameter of Inhibition Zone $F$. oxysporum growth

\begin{tabular}{ccccccc}
\hline \multirow{2}{*}{ Replicant } & \multicolumn{6}{c}{ Diameter of Inhibition Zone (Cm) } \\
\cline { 2 - 7 } & $\mathbf{5 0 \%}$ & $\mathbf{6 0 \%}$ & $\mathbf{7 0 \%}$ & $\mathbf{8 0 \%}$ & $\mathbf{9 0 \%}$ & $\mathbf{1 0 0 \%}$ \\
\hline 1 & 0,74 & 0,70 & 0,67 & 0,74 & 0,99 & 0,98 \\
2 & 0,60 & 0,60 & 0,60 & 0,68 & 0,60 & 1,02 \\
3 & 0,60 & 0,60 & 0,68 & 0,69 & 0,60 & 0,86 \\
4 & 0,60 & 0,70 & 0,73 & 0,60 & 0,97 & 0,84 \\
Average & 0,64 & 0,65 & 0,67 & 0,68 & 0,79 & 0,93 \\
Std. Deviation & 0,07 & 0,06 & 0,05 & 0,06 & 0,22 & 0,09 \\
\hline
\end{tabular}

Based on Table 1 and Table 2 shows that the higher the concentration of zodia $(E$. suaveolens) leaf extract, the greater the inhibitory power on the growth of $P$. aeruginosa and $F$. oxysporum. The high concentration of zodia (E. suaveolens) leaf extract contains many active compounds, while the concentration of zodia $(E$. suaveolens) leaf extract contains few active compounds. Therefore, $100 \%$ concentration of zodia (E. suaveolens) leaf extract able to provide the highest inhibition on the growth 
of $P$. aeruginosa and $F$. oxysporum. The statement above corresponds to the statement Qomar, Budiyanto, Sukarsono, Wahyuni, \& Husamah (2018) and Ali, Salih, \& Daffalla (2020) that the higher the concentration of the extract, the more active compounds it contains so that it can produce high microbial growth inhibition. Asadi (2016) and Fikselova et al. (2014) added that antimicrobial activity was more commonly found at higher extract concentrations.

Table 3. Summary of One Way ANOVA Antimicrobial Activity of Zodia ( $E$. suaveolens) Leaf Extract on $P$. aeruginosa Growth

\begin{tabular}{lrrrrr}
\hline \multicolumn{1}{c}{ Aspect } & $\begin{array}{c}\text { Sum of } \\
\text { Squares }\end{array}$ & df & $\begin{array}{c}\text { Mean } \\
\text { Square }\end{array}$ & \multicolumn{1}{c}{ F } & Sig. \\
\hline Between & 25.53 & 7 & 3.65 & 128.32 & .000 \\
Groups & & & & & \\
Within & .68 & 24 & .03 & & \\
Groups & & & & & \\
Total & 26.22 & 31 & & & \\
\hline
\end{tabular}

Table 4. Summary of One Way ANOVA Antimicrobial Activity of Zodia (E. suaveolens) Leaf Extract on $F$. oxysporum Growth

\begin{tabular}{lrrrrr}
\hline Aspect & $\begin{array}{c}\text { Sum of } \\
\text { Squares }\end{array}$ & df & $\begin{array}{c}\text { Mean } \\
\text { Square }\end{array}$ & F & Sig. \\
\hline $\begin{array}{l}\text { Between } \\
\text { Groups }\end{array}$ & 2.78 & 7 & 0.40 & 14.71 & .000 \\
$\begin{array}{l}\text { Within } \\
\text { Groups }\end{array}$ & .65 & 24 & .03 & & \\
Total & 3.43 & 31 & & & \\
\hline
\end{tabular}

Tables 3 and 4 show that the significance value was 0,000 and smaller than $0.050(\mathrm{P}<0.050)$. This means that there is a significant inhibitory effect of the antimicrobial activity of zodia (E. suaveolens) leaf extract on the growth of $\mathrm{P}$. aeruginosa and $\mathrm{F}$. oxysporum.

Significant inhibitory effects of the antimicrobial activity of zodia extracts ( $E$. suaveolens) are caused by the content of active compounds, such as essential oils, flavonoids, alkaloids, saponins, and tannins. The active compound contained in zodia ( $E$. suaveolens) leaf extract acts as an antimicrobial. This statement is in line with the results of the study Rahmawati, Samsumaharto, \& Iryanto (2015) states that zodia leaf extracts with n-hexane, chloroform, and water fractions contain active compounds including essential oils, flavonoids, alkaloids, saponins, and tannins that function as antibacterial agents to inhibit the growth of $P$. aeruginosa. Handayani and Nurcahyanti (2015) added that they had isolated essential oils that function as antimicrobial from zodia leaf using the water distillation method. Fajri and Agustien (2015) from their research have proven that the antimicrobial compounds from zodia leaf can inhibit the growth of Escherichia coli and Staphylococcus aureus.

Maryuni (2008) explained that active compounds of zodia (E. suaveolens) leaf extract such as essential oils and other active compounds can be designated as antimicrobials because they can inhibit the growth of Staphylococcus aureus, Staphylococcus epidermidis, Escherichia coli, and Salmonella enteritidis. Essential oils and other active compounds can damage bacterial cell walls and microbial cell membranes such as bacteria and fungi. Damage to cell walls and microbial cell membranes may cause the active compound extracts of zodia (E. suaveolens) leaf into the cell and affect the metabolic activities of bacterial cells. The metabolism of microbial cells becomes "error" resulting in death. Besides, damage to cell walls and microbial cell membrane makes molecules and compounds in the cytoplasm of cells out into the environment so that bacterial cells do not have the power to grow because all the molecules and enzymes needed for growth are lost.

Karta \& Burhannuddin (2017); Pangalinan, Kojong, \& Yamlean (2011); Soleman \& Setiawan (2017); Sari \& Nugraheni (2013); Triani, Rahmawati, \& Turnip (2017); dan Yanti, Samingan, \& Mudatsir (2016) states that antimicrobial active compounds contained in certain plant parts can increase cell membrane permeability and cell membrane damage. This causes interference with the metabolism of microbial cells so that they die. Konaté, Yomalan, Sytar, \& Brestic (2015) and Alam, Forid, Roney, Aluwi, \& Huq (2020) explains that flavonoids and tannins have important 
antimicrobial activity because flavonoids can dissolve the constituents of cell walls while tannins can inactivate microbial cell enzymes and proteins.

\section{Conclusion}

The antimicrobial activity of zodia $(E$. suaveolens) leaf extract can significantly inhibit the growth of $P$. aeruginosa and $F$. oxysporum ( $\mathrm{P}<0.05)$. The findings of this study recommend that zodia (E. suaveolens) leaf extract can be used as an antimicrobial. Furthermore, the antimicrobial of zodia $(E$. suaveolens) leaf extract can be applied in direct research in the field.

\section{Acknowledgment}

This research was funded through the Internal funding scheme IKIP Budi Utomo, Malang, East Java-Indonesia. Highest appreciation for all components involved in this research such as the head of the laboratory and laboratory assistants.

\section{References}

Abdel-Gaied, T. G., Mikhail, M. S., AbdelAlim, A. I., Seif El-Nasr, H. I., \& ElKhair, H. A. (2020). Field Application of Bio-Control Agents and Aqueous Plant Extracts for Controlling Bacterial Soft Rot and Enhancement Yield Quality of Solanum tuberosum L. cv. Diamond. Bulletin of the National Research Centre, 44(1), 1-11. https://doi.org/10.1186/s42269-02000338-4

Alam, I., Forid, S., Roney, M., Aluwi, F. F. M., \& Huq, M. (2020). Antioxidant and Antibacterial Activity of Ipomoea mauritiana Jacq.: A Traditionally Used Medicinal Plant in Bangladesh. Clinical Phytoscience, 6(1), 1-7. https://doi.org/10.1186/s40816-02000185-w

Ali, K. S. E., Salih, T. A. A., \& Daffalla, H. M. (2020). In vitro phytochemical, larvicidal and antimicrobial activities of gum arabic extract. Walailak Journal of Science and Technology, 17(3), 192$199 . \quad$ Retrieved from http://wjst.wu.ac.th/index.php/wjst/artic le/view/5540

Asadi, M. (2016). Antioxidant and Antimicrobial Activities in The Different Extracts of Caspian saffron, Crocus caspius Fisch \& C. A. Mey. ex Hohen. Caspian Journal of Environmental Sciences, 14(4), 331338. Retrieved from https://cjes.guilan.ac.ir/article_2075.ht $\mathrm{ml}$

Fajri, M. A., \& Agustien, A. (2015). Isolasi , Karakterisasi dan Potensi Bakteri Endofitik dari Tanaman Zodia ( Evodia suaveolens Scheff ) sebagai Penghasil Antibiotika, Jurnal Biologi Universitas Andalas (J. Bio. UA), 4(2), 102-106.

Fikselova, M., Kacaniova, M., Hleba, L., Mellen, M., Vukovic, N., \& Dzugan, M. (2014). Antimicrobial and Antioxidant Activity of Natural Honeys of Different Origin. Scientific Papers: Animal Science and Biotechnologies, 47(2), 218-224. Retrieved from http://spasb.ro/index.php/spasb/article/v iew/1697

Handayani, P. A., \& Nurcahyanti, H. (2015). Ekstraksi Minyak Atsiri Daun Zodia (Evodia Suaveolens) Dengan Metode Maserasi dan Distilasi Air. Jurnal Bahan Alam Terbarukan, 4(1), 1-7. https://doi.org/10.15294/jbat.v3i1.3095

Idris, J., Som, A. M., Musa, M., Ku Hamid, K. H., Husen, R., \& Muhd Rodhi, M. N. (2013). Dragon Fruit Foliage PlantBased Coagulant for Treatment of Concentrated Latex Effluent: Comparison of Treatment With Ferric Sulfate. Journal of Chemistry, 2013(1), 1-8.

https://doi.org/10.1155/2013/230860

Jamilah, B., Shu, C. E., Kharidaah, M., Dzulkifly, M. A., \& Noranizan, A. (2011). Physico-chemical Characteristics of Red Pitaya ( Hylocereus polyrhizus ) Peel. Internasional Food Research Journal, 18(18), 279-285.

Jumjunidang, D., R., \& Yanda, R. P. (2016). Research on Management of the Dragon Fruit Diseases in Indonesia. In 
Regional Workshop on The Control of Dragon Fruit Diseases di Mekong Institue Thailand (pp. 4-8). Retrieved from

https://balitbu.litbang.pertanian.go.id/i mages/leaflet/pitaya.pdf

Karta, I. W., \& Burhannuddin. (2017). UJI Aktivitas Antijamur Ekstrak Akar Tanaman Bama (Plumbago zeylanica) Terhadap Pertumbuhan Jamur Trichophyton Mentagrophytes Penyebab Kurap Pada Kulit. Jurnal Media Sains, 1(1), 23-31. Retrieved from

https://jurnal.undhirabali.ac.id/index.ph $\mathrm{p} / \mathrm{mp} 3 /$ article/view/192

Konaté, K., Yomalan, K., Sytar, O., \& Brestic, M. (2015). Antidiarrheal and Antimicrobial Profiles Extracts of The Leaves From Trichilia emetica Vahl. (meliaceae). Asian Pacific Journal of Tropical Biomedicine, 5(3), 242-248. https://doi.org/10.1016/S22211691(15)30012-5

Maksymiv, I. (2015). Pesticides: Benefits and Hazards. Journal of Vasyl Stefanyk Precarpathian National University, 2(1), 70-76. https://doi.org/10.15330/jpnu.2.1.70-76

Maryuni, A. E. (2008). Isolasi dan Identifikasi Senyawa Antibakteri Minyak Atsiri Daun Zodia (Evodia sp.). Bogor. Retrieved from https://repository.ipb.ac.id/handle/1234 56789/41386

Noor, M. I., Yufita, E., \& Zulfalina. (2016). Identifikasi Kandungan Ekstrak Kulit Buah Naga Merah Menggunakan Fourier Transform Infrared ( FTIR ) dan Fitokimia Identification Content of the Red Dragon Fruit Extract Skin Using Fourier Transform Infrared (FTIR) and Phytochemistry. Journal of Aceh Physics Society (JAcPS), 5(1), 14-16. Retrieved from http://www.jurnal.unsyiah.ac.id/JAcPS/ article/view/4939/4205

Pangalinan, F. R., Kojong, N., \& Yamlean, P. V. Y. (2011). Uji Aktivitas Antijamur Ekstrak Etanol Kulit Batang
Rambutan (Nephelium lappaceum L.) Terhadap Jamur Candida Albicans Secara In Vitro. PHARMACON, 1(1), 7-12. Retrieved from https://ejournal.unsrat.ac.id/index.php/p harmacon/article/view/439

Paundrianagari, S. A., Setyowati, N., \& Qonita, R. A. (2019). Strategi Pengembangan Agribisnis Buah Naga Organik Di Kabupaten Wonogiri. Jurnal Social Economic of Agriculture, $8(2)$, 55-66. https://doi.org/10.26418/j.sea.v8i2.3479 0

Prayitno, T. A., \& Elan, A. A. (2018). Media Transfer Pengetahuan: Pengembangan Buku Saku Berbasis Riset Melalui Model Borg and Gall. In Seminar Nasional Pendidikan dan Pembelajaran II Universitas Nusantara PGRI Kediri (pp. 1263-1272). Universitas Nusantara PGRI Kediri. Retrieved from http://conference.unpkediri.ac.id/index. $\mathrm{php} / \mathrm{semdikjar/semdikjar2/paper/view/2}$ 64

Qomar, M. S., Budiyanto, M. A. K., Sukarsono, Wahyuni, S., \& Husamah. (2018). Efektivitas Berbagai Konsentrasi Ekstrak Daun Kayu Manis (Cinnamomum burmannii [Ness.] BI) Terhadap Diameter Zona Hambat Pertumbuhan Bakteri Staphylococcus epidermidis. Jurnal Biota, 4(1), 12-18. https://doi.org/10.19109/biota.v4i1.145 4

Rahmawati, I., Samsumaharto, R. A., \& Iryanto, E. Z. (2015). Uji Aktivitas Antibakteri Fraksi n-Heksan, Kloroform dan Air dari Ekstrak Daun Zodia (Evodia sauveolens, Scheff.) Terhadap Pseudomonas aeruginosa ATCC 27853. Jurnal BIOMEDIKA, 8(2), 9-14. https://doi.org/10.31001/biomedika.v8i 2.199

Rahmawati, I., Samsumaharto, R. A., \& Iryanto W, E. Z. (2015). Uji Aktivitas Antibakteri Fraksi n-Heksan , Kloroform dan Air dari Ekstrak Daun 
Zodia (Evodia sauveolens, Scheff.) Terhadap Pseudomonas aeruginosa ATCC 27853. Jurnal BIOMEDIKA, 8(2), 9-14. https://doi.org/10.31001/biomedika.v8i 2.199

Riska, Jumjunidang I., Muas, \& Istianto, M. (2016). Pitaya Diseases in Indonesia. In Regional Workshop on The Control of Dragon Fruit Diseases di Mekong Institue Thailand (pp. 4-8).

Sari, E. R., \& Nugraheni, E. R. (2013). Antifungal activity test of Piper retrofractum leaf ethanol extract on Candida albicans growth. Biofarmasi, 11(2), 36-42. https://doi.org/10.13057/biofar/f110202

Setiawan, A., \& Soelistyo, A. (2017). Analisis Pendapatan Petani Buah Naga Di Desa Sambirejo Kecamatan Bangorejo Kabupaten Banyuwangi. Jurnal Ilmu Ekonomi, 1(2), 153-162.

Soleman, D., \& Setiawan, N. C. E. (2017). Aktivitas Antifungi Ekstrak Metanol Kulit Batang Jambu Mete terhadap Candida albicans. JC-T (Journal CisTrans): Jurnal Kimia Dan Terapannya, l(2), 25-29. https://doi.org/10.17977/um026v1i2201 $7 \mathrm{p} 025$

Sudarjat, Suminar, E., Qanit, M. A. H., \& Mubarok, S. (2019). Aplikasi Teknologi Budidaya Buah Naga untuk Daerah Pesisir di Kelurahan Kalijaga, Kecamatan Harjamukti, Kota Cirebon. Jurnal Pengabdian Pada Masyarakat, 4(1), 53-60. https://doi.org/10.30653/002.201941.75

Swastika, S., Yuliani, N., \& Saputra, S. (2012). Hama \& Penyakit Buah Naga, pp. 1-2.

Syromyatnikov, M. Y., Isuwa, M. M., Savinkova, O. V., Derevshchikova, M. I., \& Popov, V. N. (2020). The effect of pesticides on the microbiome of animals. Agriculture (Switzerland), 10(3), 1-14. https://doi.org/10.3390/agriculture 1003 0079.

Triani, Rahmawati, \& Turnip, M. (2017).
Aktivitas antifungi ekstrak metanol jamur kuping hitam (Auricularia polytricha (Mont .) Sacc .) terhadap Aspergillus flavus (UH 26). Jurnal Labora Medika, 1(2), 14-20. Retrieved from

https://jurnal.unimus.ac.id/index.php/JL $\mathrm{abMed} /$ article/view/2871.

Wibowo, A., Widiastuti, A., \& Agustina, W. (2011). Penyakit-penyakit Penting Buah Naga di Tiga Sentra Pertanaman di Jawa Tengah. Jurnal Perlindungan Tanaman Indonesia, 17(2), 66-72.

Widiastuti, A., Agustina, W., Wibowo, A., \& Sumardiyono, C. (2011). In Vitro Test of Pesticides Effectiveness Against Some Phatogens of Important Diseases In Dragon Fruit (Hylocereus sp.). Jurnal Perlindungan Tanaman Indonesia, 17(2), 73-76. Retrieved from

https://jurnal.ugm.ac.id/jpti/article/view 19828.

Yanti, N., Samingan, \& Mudatsir. (2016). Uji Aktivitas Antifungi Ekstrak Etanol Gal Manjakani (Quercus infectoria) terhadap Candida albicans. Jurnal Ilmiah Mahasiswa Pendidikan Biologi, 1(1), 1-9. Retrieved from http://jim.unsyiah.ac.id/pendidikanbiologi/index. 